\title{
THINKING STYLES AND COMPUTER ENGINEERING TRAINING: AN EMPIRICAL STUDY
}

\author{
Dr. Jaime Huincahue, Vicerrectoría de Investigación y Postgrado, Universidad Católica del Maule, Chile \\ E-mail: jhuincahue@ucm.cl
}

MSc. Claudio Gaete-Peralta, Departamento de Matemáticas y Física, Universidad Bernardo O’Higgins, Chile. E-mail: claudio.gaete@ubo.cl

Eng. Viviana Garrido Véliz, Vicerrectoría de Investigación y Postgrado, Universidad Católica del Maule, Chile E-mail: vgarrido@ucm.cl

ARTICLE INFO

Original Research

Received: February, 01.2019.

Revised: March, 02.2019.

Accepted: March, 18.2019.

doi:10.5937/ijcrsee $1901021 \mathrm{H}$

UDK

159.955.072-057.875

378.147::004

Keywords:

thinking styles,

professional formation,

referential cognitive graduate profile. empirical study,

bernardo o 'higgins.

\section{A B S T R A C T}

This study shows the qualitative construction of a Referential Cognitive Graduate Profile (RCGP) for the Computer Engineering program of the University of Bernardo O'Higgins (UBO) in Chile, based on the theory of Mental Self-Governance and by using three data-gathering methods: document analysis, interviews, and questionnaires, reflecting the professional competencies expected by the end of the training, set forth by both the institution and program management. The proposed model allows to contrast the different thinking styles (TSs) found with the ones preferred by students in different levels of formation independently. With this purpose in mind, by using a quantitative methodology, $88 \%$ of male students in the program completed the questionnaires to determine these preferences, enabling us to perform a correspondence analysis through Fisher's exact test. The RCGP results show evident preference for the legislative, executive, hierarchical, and external styles of thinking and clear differences between the preferences of students and of the RCGP. Finally, we discuss about various ways to create new means to strengthen and upgrade both the program's graduate profile and the RCGP with the purpose of benefitting the formation of Computer Engineers and the future of the RCGP model.

(C) 2019 IJCRSEE. All rights reserved.

\section{INTRODUCTION}

Among the many concerns for improving the training processes in undergraduate programs in Chile, there is a strong and ongoing interest that universities share, which is getting to know their students, whether it is on a socio-economic, cultural and/or cognitive level, so that said processes can be visualized and improved upon for the benefit of these students-bearing in mind that, for many of them, the transition from secondary to higher education is a turning point (Donoso, Donoso and Arias, 2018). Furthermore, higher education

\footnotetext{
Corresponding Author

MSc. Claudio Gaete-Peralta, Departamento de

Matemáticas y Física, Universidad Bernardo

O'Higgins, Chile.

E-mail: claudio.gaete@ubo.cl
}

\section{cc) (†) $\odot$}

This work is licensed under a Creative Commons Attribution - NonCommercial - NoDerivs 4.0. The article is published with Open Access at www.ijcrsee.com institutions are making efforts to reduce desertion rates in every stage of their undergraduate programs, a situation that could be addressed by continuously searching for the enhancement of teaching practices until a permanent upgrade for their study programs is achieved (Cortés, Arellano and Vázquez, 2016).

However, there are other matters as well that higher education institutions want to resolve. In Chile, every university program reflects a vision of the wanted professional, which is described-explicitly-in the learning outcomes and/or the desired professional competencies for graduates; this is known as a graduate profile, and it is what every higher education institution aims to reach. Nevertheless, achieving such goal is a rather complex task which, at the same time, can be approached from multiple perspectives. One such perspective is cognition, from where one can study and learn about the preferences in methods used to carry out different tasks required for specific professions. For instance, (García Ahumada, 2005, 194-195) realized that these method preferences needed in a future profes- 
sional who graduates in medicine are related to the analysis and organization of information, involving an integral view of problems, interaction with others and the search for new ways to heal the patients' ailments.

In the present case, this investigation will be focusing on the Computer Engineering program of the University of Bernardo O'Higgins (UBO), where, from a cognitive point of view, we will seek to recognize which are the aforementioned preferences, which will be described in this investigation based on Sternberg's thinking styles (1997). These styles vary and evolve through time and can be taught and strengthened (Sternberg, 1999, p. 90). In order to fully understand how to teach and strengthen said styles, it is important to know, also, which of these are present in the Computer Engineering students of the UBO for us to be able to compare between the styles that the institute wishes to promote and the styles that it actually promotes. This way, the stated institution will count with a reference that will allow them to make - if needed - the corresponding modifications to produce a variation and/or an evolution of the TSs in accordance with its requirements. For that reason, one of the questions that lead this investigation is what are the similarities and differences between the TSs recognized in the students of Computer Engineering of the UBO and the ones recognized in a reference profile of a graduate from said study program?

To answer the previous question, it is necessary to address two issues before: firstly, we need to deepen our understanding of what is actually a TS, understood from the Mental Self-Government Theory, which will be described below; and, secondly, to discuss the general and specific objectives of this investigation, which will be done in section three.

\subsection{Theoretical framework}

Sternberg (1997), in his Theory of the Mental Self-Governance (TMSG), defines styles as "a way of thinking. It is not an ability, but rather, a preferred way of using the abilities one has. (...) A style refers to how someone likes to do something" (Sternberg, 1997, p.8). The styles involve many variables, such as the environment, culture, schooling, upbringing and gender that can give shape to students' way of thinking.

Sternberg and Grigorenko (2001) affirms that the styles are both measureable and teachable, from socialization processes, or di- rectly through teaching practices, which is relevant for the empowerment of a person's TSs in a specific situation, providing relevance of interest to the educational dimension.

A hypothesis that the TMSG assumes is metaphorized by Sternberg (1997) between the personal preferences and those that are socially visualized:

The forms of government we have in the world are not coincidental. Rather, they are external reflections of what goes on in people's minds. They represent alternative ways of organizing our thinking. Thus, the forms of government we see are mirrors of our minds (Sternberg, 1997, p.19).

Assuming social diversity, the hypothesis suggests - among other things - raising the personal preferences of students as a cognitive variable in learning, which might indicate why a student has preferences in performing certain types of activities, or why a specific use of knowledge is more attractive. Responding better to teaching practices over others; but, on the other hand, it also suggests the promotion of flexibility among TSs as a didactic practice in teaching and learning processes.

The TSs are divided into five dimensions: functions, forms of thinking, levels, scopes and leanings of mental self-governance. The styles are summary according to table 1.

Table 1. Summary of TSs with the five thinking dimensions.

\begin{tabular}{lllll}
\hline Functions & Forms & Levels & Scopes & Leanings \\
\hline Legislative & Monarchic & Global & Internal & Liberal \\
Executive & Hierarchic & Local & External & Conservative \\
Judicial & Oligarchic & & & \\
& Anarchic & & & \\
\hline
\end{tabular}

Source: (Sternberg, 1997, p.26).

The styles' functions refer to the type of work that individuals perform in their daily activities, their preferences for carrying out certain tasks or projects, and the way they approach certain situations in order to adapt to their sociocultural environment. The forms refer to the way one approaches the world and its problems, either from one perspective, several or randomly. The levels refer to how one approaches a problem to reach a solution, either in a general or a particular way. The scope refers to the way people interact either with themselves or with others. Lastly, the leanings refer to the tendencies that exist when seeking or avoiding change when addressing different problems or issues. 


\subsubsection{Characterization of styles}

In relation to the functions of thinking, people who prefer the Legislative style tend to plan how to solve problems, following their own rules. In addition, they prefer activities that allow them to put their creative capacity at stake. On the other hand, those people who prefer the Executive style prefer to follow the rules and work with the structures that already exist, instead of creating them; also, they prefer to perform activities when they are told what and how to do things. In the case of those who prefer the Judicial style, they have the tendency of analyzing, comparing, contrasting, evaluating, correcting and judging ideas, rules, procedures, structures, contents and existing problems.

As for the forms of thinking, people who prefer the Monarchical style are characterized as those who approach problems from a single perspective, taking into account only one objective at a time; thus, they have a limited sense of priorities and alternatives, leading them to see things from one single point of view, being motivated by a single goal or need at the same time, paying attention only to aspects that interest them and considering unimportant everything that is not related to their preferences. Moreover, when speaking or writing, they are guided by one main idea, preferring to discuss problems and general issues instead of details. People with a Hierarchical style address their problems from various perspectives, establishing a set of hierarchies and needs, knowing they cannot reach all goals equally and understanding that some are more important than others. People who prefer the Oligarchic style often give the same importance to several objectives that are presented to them. Finally, those people who prefer the Anarchic style usually approach problems in a random way, using different procedures for their solution. In addition, they tend to be very creative, managing to see solutions that others often overlook.

With regard to levels of thinking, people who prefer the Global style, approach problems by ignoring or simply rejecting the details. On the contrary, people who prefer the local style, when facing problems tend to focus on the details.

With respect to the styles'scope, people who prefer the internal style are usually introverted and seek to solve problems individually, sometimes distant from other people. On the contrary, extroverts prefer the external style. In addition, they like to work as a team and interact with the rest of the people.

Style leanings have two opposite poles: on the one hand, there is the liberal style, preferred by people who tend to go beyond the existing procedures and rules, and, on the other hand, there is the conservative style, preferred by those people who tend to avoid change, looking for old strategies to solve problems that arise.

\subsection{State of art}

From an educational focus, there are several investigations that use the TMSG, which highlight socioeconomic aspects (e.g., Sternberg and Grigorenko, 1995), academic performance (e.g., Cano-García and Huges, 2000; Grigorenko and Sternberg, 1997; Zhang and Sternberg, 1998, Zhang, 2002; Zhang, 2004), and learning styles (e.g., Zhang and Sternberg, 2000).

Proposals about classroom resources have also been made. Spangenberg (2012) explains how to build support guidelines on choosing two mathematical topics in 8th grade students, showing the relationships between cognitive learning requirements and the use of a mathematical object, concluding with a sequent development of TS flexibility. In this case, the author considered as a goal the development of creativity through the promotion of specific TSs, considered as valid distinctive components to decide which mathematical educational section is fitting for students.

Agreeing with Betoret (2012), the majority of the studies that used the TMSG have focused on students, achieving set interest outcomes for the understanding of descriptive and interpretive phenomena. In this direction, but from a referential approach, it is interesting to study instruments or models to strengthen professional training processes. Regarding that, García Ahumada (2005) studies the relationships between the TSs found in the graduate profile and students of medicine who are in their second and fourth year, with the objective of determining a certain coincidence degree; establishing a first approximation regarding the use of a referential structure, considering a single source of data for such a task: the graduate profile.

If we take into consideration the social component of the case being studied, it is possible to add more data sources for referential construction, recognizing realities of the educational institution that are relevant. In relation to that, a sensitive variable in the educa- 
tional process — and particularly in Chile - is the socioeconomic factor, and, agreeing with Lizasoain et al, (2007), such variable cannot be omitted in references for their training process, because they are crucial in academic performance (Vargas, 2007).

In the case of the UBO's Computer Engineering program, it is interesting to study the students and the graduate profiles from a cognitive perspective, since this kind of research can be used as an instrument that continuously provides reinforcement and updates to professional training methods, being capable to propitiate flexibility in the TSs for the new students, prioritizing styles that are in accordance with future professional tasks. From this, we could say that there are TS of that are more priority than others by the UBO. Taking all this into account, our goal is to identify which thinking styles are appropriate for UBO's computer engineering program, which will allow us to contrast the referential profile of graduates of the program with the different stages of training of their students.

This would allow contributing, from a cognitive educational paradigm (Sternberg, 1997), to the establishment of strategies that optimize their training practice. For this, the following specific objectives are defined:

1. Constructing a Referential Cognitive Profile of the Graduate (RCGP) by means of a data triangulation process, between the reference profile from the director of the UBO's Computer Engineering program and the associated documentation to the program of the graduation profile.

For the investigation, the said associated documentation refers to the program objectives, occupational field and graduate profile. This objective allowed us to identify the appropriate thinking styles for UBO's computer engineering program.

Next, the focus of the study shifts towards the students:

2. Identifying the existence of association of the TSs in the students' responses at the initial, intermediate and final levels.

Both results associated with the objectives have a qualitative nature and are determined through the TMSG, being possible to consider the next objective from a vertical comparison of such results:

3. Comparing the results of association of TSs with the results of the RCGP model.

\section{MATERIALS AND METHODS}

Agreeing with Spangenberg (2012), in order to address our objectives correctly, comparative studies associated with students and institutions need to be approached with qualitative and quantitative methods.

\subsection{Context}

The University of Bernardo O'Higgins is an academic institution in Chile that was founded in the year 1991, opening the Computer Engineering program in the School of Engineering, Science and Technology, in Santiago, Chile, in the year 2011. The data was taken in June, 2016, when the program had already generated graduates and had current students in all generations.

In Chile, the socio-economic differences among students are commonly linked to their academic performance (SIMCE, 2013, p. 47), which is measured through the SIMCE standardized test (Education Quality Assessment System); a tool-developed and published by the Education Quality Assurance Agencythat allows for the assessment of students' learning process in certain subjects. In the case of mathematics, students coursing their second year of high school, or who are fifteen to sixteen years old, that attend municipal schools (public) tend to get lower scores than students attending semi-private schools (partially funded by the state), and these last tend to get lower scores than students attending private schools. Such pattern hasn't changed in the last fifteen years (Agency of Education Quality, 2018a, 2018b).

The data in the table 2 makes evident that the mentioned pattern has been kept; the students' academic performance fluctuates according to the schools they attend, being of interest to have a study of this nature, since it could potentially be used to help bridge the existing gap between these groups which do require strong support (Donoso and Cancino, 2018 , p.239) on the academic and social aspect. 
Table 2. Procedence college in some generations and Simce results.

\begin{tabular}{lcccc}
\hline $\begin{array}{c}\text { Procedence } \\
\text { college }\end{array}$ & 2014 & 2015 & 2016 & $\begin{array}{c}\text { Simce } \\
\text { results }\end{array}$ \\
\hline Municipal & $33,33 \%$ & $43,75 \%$ & $13,04 \%$ & 241 \\
\hline $\begin{array}{l}\text { Particular } \\
\text { subvencioned }\end{array}$ & $58,33 \%$ & $56,25 \%$ & $82,61 \%$ & 270 \\
\hline Particular & $8,33 \%$ & $0 \%$ & $4,35 \%$ & 335 \\
\hline
\end{tabular}

Enrollment percentages from generations 2014 to 2016 in Computer Engineering in the UBO according to the students' school backgrounds. The far-right column shows the SIMCE scores obtained in mathematics by the students of generation 2012 in Chile. Source: Department of Integral Formation (2016) [DFI].

\subsection{Qualitative method}

The participant for the construction of the RCGP model, is the director of the UBO's Computer Engineering program, being the only one who has held his position in the institution since the start of the program up until now, when the data was collected.

As instrument, a semi-structured interview is created to characterize the TSs that the director considers as a reference for their program, since they are aware of the skills and competencies needed to be able to carry out the tasks the students will have to perform in the labor world in the future. Thus, there was a first preparation of the questionnaire, which must be piloted and adjusted, achieving precise aspects of relevance according to the objectives of each question. The questionnaire is based on the explanation of the desired skills and the description of the types of tasks that a graduate of this program must perform, so that clear characteristics or principles of each TS are recognized. After a first analysis of the data extracted from the interview transcript, we realized a second interview was going to be necessary in order to address aspects of analysis validation.

While adressing the specific objective $\mathrm{N}^{\circ} 1$, we start to realize that the RCGP has a multifactor nature, where the type of information source determine its construction, because these sources have an underlying visualization of what is expected cognitively in computerengineering work. To continue, several sources are considered, that will allow us to study and build this conceptual profile in context, it being relevant to perform a triangulation of data (Cisterna Cabrera, 2005; Denzin 1990). We decided for this type of methodology since the contextualization of data and addressing its social diversity is considered essential to make an objective and accurate description and interpretation (Cisterna Cabrera, 2005).

For a coherent construction of the RCGP, a systematic strategy is proposed between the chosen sources; additionally, in order to minimize the bias that may exist in the analysis of each researcher individually (Gavira and Osuna, 2015), a triangulation among researchers is performed (Valencia, 2000) throughout the whole process. All this reflects a correct and adequate scenario for the triangulation of data (Donolo, 2009).

The information sources are the following: 1) the director of UBO's Computer Engineering program; 2) UBO Documentation (UBO-D), composed of the Objectives, Occupational field and Graduate Profile of the Computer Engineering degree; and 3) the report of the Department of Integral Training (DFI for its acronym in Spanish) of UBO. The latter provides socioeconomic and psychoeducational information on the students of each generation of the program. If we take into account such sources of data for the analysis, it will minimize the individualized bias of the informant (García Ahumada, 2005).

The director, as information source, will allow us to describe the student's training environment, and specifically recognizing the skills that a graduate from this program acquires at the end of the curriculum structure. During this process, the director of the program is the one who leads its projects, based on his knowledge, professional experiences, beliefs and institutionalization; therefore, the director is asked to answer the MSG Thinking Styles Inventory questionnaire based on the preferences expected in the graduates.

The data of the UBO-D is extracted from public information declared by the institution from the year 2016 up to the present date (UBO, 2018), based on the skills and abilities expected in the disciplinary domain and declaring certain types of tasks that the graduate will perform in their career. Finally, the DFI data is synthesized in an internal diagnostic report of the Computer Engineering degree (DFI, 2016) and offered for the present investigation. The DFI document is known by the director. An example of some data are: the parents' education, educational results of the admission previous to entering the program, and the family's economic situation, under- 
standing that "the relationship that exist between students' socio-economic situation and their access to education in a neoliberal society such as the Chilean" (Cisterna Cabrera, 2005 p. 64).

This way, the RCGP is the result of the triangulation between the questionnaire data, the interview transcript analysis, and the declared cognitive profile for the institution in UBO-D. Such analysis is positioned between two axes that govern the entire process, one that characterizes a socioeconomic context from the DFI and another that provides an objective interpretation of the data. The diagram for the construction of the data triangulation is shown in Figure 1.

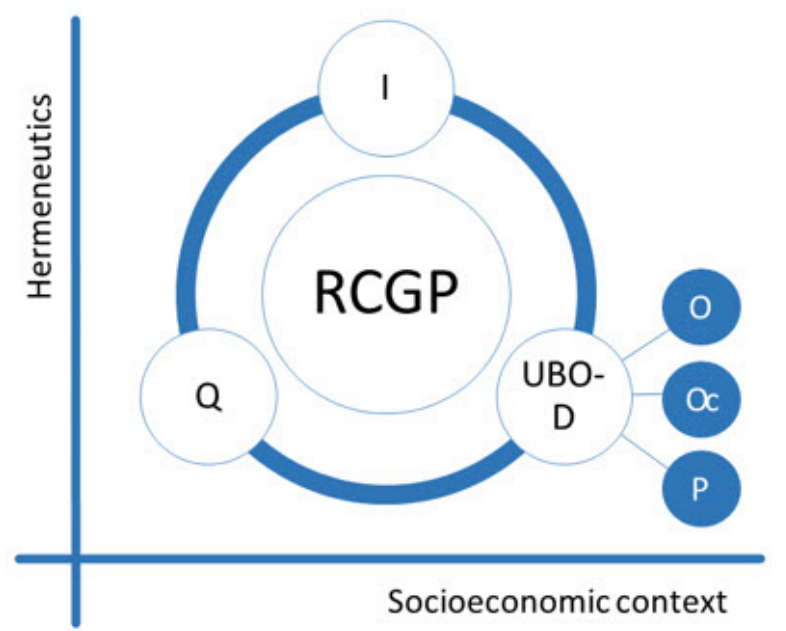

Figure 1. The RCGP model for the UBO's Computer Engineering program. The considered components are: I: interview; Q: questionnaire; UBO-D: UBO documentation; O: objectives; Oc: occupational field; P: graduate profile.

In the study, interpretation, analysis and construction of the RCGP model, it is assumed that its validity and reliability rests ultimately on the researcher's rigor (Cisterna Cabrera, 2005, p. 62), which form of construction comes from a hermeneutic rationality, in accordance with Cisterna Cabreras' statements (2005).

Furthermore, the students can participate directly or indirectly in the data; for instance, they could take part in it through the principal's opinion or the information in the D-UBOs, being the information on the socioeconomic aspect of high relevance for the interpretation of data, its analysis and the results of the RCGP model.

\subsection{Quantitative method}

The participants considered for this study are 38 male students in the Computer Engineering program of the UBO in June of 2016. Since only 4 students were women, representing only $9 \%$ of the total, the data and its interpretation wouldn't have been reliable for use. The participants represent $88 \%$ of students; each accepted to take part in the investigation under an informed consent, adding name and sex in the form. The sampling was performed by considering a significance of $5 \%$.

Understanding that the knowledge in students in the program is progressive, an initial, intermediate, and final classification level is constructed according to the number of specialty courses taken, taking into account that its curricular structure admits basic or general subjects. The initial level corresponds to students who are attending or who have completed, at most, 5 of the specialty subjects; the intermediate corresponds to those attending or who have completed from 6 to 17 specialty courses; while the final level corresponds to those who have completed from 18 to 25 specialty courses. The data was taken during an academic semester, which makes it impossible for the students to have been surveyed in more than one level.

The distribution by section was $86 \%$, $94 \%$ and $83 \%$ of respondents in the initial, intermediate and final program levels, delivering a total of 18,15 and 5 male respondents by level, respectively.

The MSG Thinking Styles Inventory (Sternberg, 1999) uses a 104-item, psychometric questionnaire in Spanish, which considers the measurement of the $13 \mathrm{TSs}$, generating a distinction in gender and occupation; specifically when considering the measurement for adult men and women who are or not in college, being relevant to the study group and validated in the research practice, since it has been used in cohort educational studies such as Bishop and Foster (2011); Gaete-Peralta (2015); González-Pienda et al, (2004); Gutiérrez and Krumm (2012); Huincahue (2014); López Martínez and Martín Brufau (2010); Saxena and Aggarwal (2011); among many others. That being said, to address objective $\mathrm{N}^{\circ} 2$, the questionnaire was used, where the aim of finding some existence of significant association between the TSs and the perception of students regarding their preferences in academic-labor scenarios, considering the independent data extraction for each study level. 
Each style is composed of 8 items measured on the Likert scale "being 1 if the affirmation does not fit at all, that is, if it almost never does things like that and 7 if the statement fits completely, that is, if one always does things like that" (Sternberg, 1999, p. 28). The score associated for each style is calculated through an average, which qualifies the TSs in 6 categories, from very low to very high.

To measure the reliability of the construct, a Cronbach's alpha reliability analysis was performed for each measurement style, considering the categories described by George and Mallery (2003).

Using the R-project software, a correlation analysis was applied using Fisher's exact test. Due to the distribution of absolute frequencies and the differences between the number of categories, rows, and columns, this analysis was performed internally at each study level for the 5 dimensions: functions, forms, levels, scopes and leanings. After that, a correspondence analysis was performed to observe the distribution and the association graphic between the mentioned variables, specifically those that where significant association evidence was found.

\section{RESULTS}

\subsection{RCGP results}

\subsubsection{Construct}

The MSG Thinking Styles Inventory's application to the director with respect to preferences expected by the graduates of the program shows the following results: legislative: low middle (4.3); executive: high (5.8); judicial: high middle; monarchic: low middle; hierarchic: high (7.0); oligarchic: very low (1.8); anarchic: very low (2.5); global: low middle (3.5); local: very low (2.4); internal: very low (2.0); external: high (5.8); liberal: low middle (4.3); and conservative: low middle (3.8). This results show preferences for three styles: executive, hierarchical and external.

\subsubsection{Interview}

The director initially talks about the students who enter the program, highlighting those students with a different personality in comparison with other engineers, since "many times they are more introverted (...) the extreme cases are those that I call autistic, not very sociable people". (according to DFI data, the average percentage of the generation of students from the program that have a diagnosed disability is $24,28 \%$, considering visual disability, attention deficit and others).

Upon realizing the previous perception, an intention to change the attitude of the students springs up in the director's mind; "what I try telling them, since they enter the program, is to buy the story and that they are going to be engineers and ,therefore, they will have to work with people, to lead teams, etc.". "To buy the story" is a Chilean idiom, used to promote self-confidence and self-esteem by believing in ourselves facing problems with a positive attitude. In Economía y Negocios (2016) a use of this expression can be found.

The director shows interest for making the students stop being introverted, giving reasons entirely work-related, making evident his preference for the external TS, since the tasks and activities that are to be developed in the future must be framed in environments that favor certain attitudes or preferences:

Therefore, what I have to work on is to try and make the new students, who are usually more introverted and more likely to play "behind the scenes", "get in the game"... Because, if truth be told, if he's going to become an engineer, he will have to sell or design projects, to lead teams, because there are fine lines involved and deadlines to meet, then one must have the ability to talk with the entire team, encourage and make them perform to their maximum capacity.

For the creation and design sale of the projects, it is desirable to be able to properly organize the requested tasks, and, many times, the computer engineer is expected to participate and collaborate in multidisciplinary environments, where, for the director, optimizing is as a continuous skill of a computer engineer. Thus, he describes scenarios where one will participate, showing the multifocality of tasks and the need for a creative professional for good preparation:

This is hard engineering. One must have the ability to put themselves in many situations and look for the best, fastest, most efficient solution, one that takes up less memory... engineering problems, effectively... and be very creative.

The metaphor of hard engineering is understood in a sense of a technical and systematic rigor required in their professional work, whether to optimize a website or to build a 
software.

The truth is that I need to be innovative, creative. Currently, the whole world is asking for it, because, nowadays, these are some of the most used resources, but that does not mean that I am not rigorous in terms of having some way to know how I'm going to design the software or how I'm going to run it, because it's not just a person that participates in the software design.

Such tasks fit better with the legislative and executive styles, since it is a characteristic of said style to solve problems which solutions must be created or constructed; for example, in the optimization of a web site or software construction. Additionally, the theoretical rigor in programming aspects requires the ability to achieve a hierarchical organization of tasks to accomplish the objectives.

In this regard, the bivalent work of the functions exercised is highlighted, whether in the technical and natural field of the discipline, or in the multidisciplinary practice declared by the director, which is where the product's function or the solution reached (for example, to devise a software that optimizes the informative and digital work of a public service) is reflected. In this sense, the global and local TSs are recognized, since, in certain aspects of their work, they are required to use specific knowledge, while also knowing and understand the scientific and/or technical impact of their job.

\subsubsection{UBO-D}

For the three data components analyzed $(\mathrm{O}, \mathrm{Oc} \& \mathrm{P})$, only two TSs were clearly recognized: the declaration of professional skills $(\mathrm{P})$ and the program's objective $(\mathrm{O})$, which recognizes the graduate as someone able to work with professionals from other domains that have an end in common, such as software engineering, networks, web programming, mobile programming and computer project management (UBO, 2018). This suggests the promotion of collaborating with work teams, which is related to the external TS.

On the other hand, the importance of planning, analyzing, designing, implementing, documenting and managing computer system projects for the professional future is also stated. Which poses a particular development of creativity and a preference for legislative style, because, according to Sternberg (1997, p.20), "creative people need not only the ability to come up with new ideas, but also the desire to".

\subsubsection{RCGP results}

In respect to the functions of thinking, a preference for the legislative style is recognized in the interview and in the D-UBO, yet it is ranked with a "low middle" preference in the questionnaire. However, another aspect granted by the DFI is that the students who enter this program scored close to 500 points on the PSU (considering that a maximum of 850 points and a minimum of 450 points is needed on the University Selection Test to apply to these type of universities), this score being what does not allow them to enter into the best universities in the country. In addition, they have similar results in the NEM (secondary education average grading from 14 to 17 years old), which affects the academic-university performance, specifically in the perception and expected achievements of the program in the initial level.

This means that the efforts made to achieve this type of preferences are important. The questionnaire shows a reduction of preference for the legislative style, which is in accordance with the type of students the UBO admits, and does not discard the preference for the legislative style, since creativity is even presented as a necessity.

The executive function of thinking is clearly preferred in the questionnaire and interview. Moreover, although there is no clear evidence in the D-UBO, it is implicitly visualized in tasks such as planning, project management, execution or implementation. These tasks also entail a requirement for the hierarchical TS, which is preferred in the questionnaire and the interview, and, therefore, is considered preferred for the RCGP.

The Local and Global levels of thinking are clearly preferred in the interview, although the preferences in the questionnaire are low and are not lucidly recognized in UBO-D.

Regarding the scope of thinking, there is evidence in the three samples taken that the external thinking is clearly preferred.

In summary, and based on the analysis performed and synthesized, the RCGP proposes preferences for the UBO's Computer Engineering program pointing towards legislative, executive, hierarchical and external thinking. These are the appropriate thinking styles for UBO's computer engineering program. 


\subsection{Students' thinking styles by level}

The data analysis was performed considering the TSs in its 13 varieties as shown in table 1, in a quantitative way (scores) and qualitative way, following the descriptions made in the theoretical framework.

\subsubsection{Construction of reliability analysis}

To measure the reliability of the items in each TS, the calculation of Cronbach's Alpha coefficient is described by George \& Mallery (2003, p. 231). The results are as follows: legislative: good (0.814); executive: good (0.806); judicial: acceptable (0.721); monarchical: questionable (0.618); hierarchical: acceptable (0.771); oligarchical: poor (0.545); anarchical: questionable (0.633); global: acceptable (0.722); local: questionable (0.660); internal: acceptable (0.773); external: excellent (0.921); liberal: good (0.896); conservative: good (0.810).

From what is declared by Jisu, Delorme and Reid (2006), the reliability value in explora-tory investigation should be equal to or greater than 0.6 ; while in confirmatory studies it should be between 0.7 and 0.8 . The present investigation establishes an average of 0.745 , showing that, on average, and in most of the items, there is high reliability.

On the other hand, the dimensions associated to the TMSG of Table 1 are used, where the objective is to identify the existence of association between the students' perception of their professional training and the TSs, considering the levels defined in 4.1.

Next, the correspondence analysis is performed on each level, using Fisher's exact test. The statistically valid results $(p<0.05)$ are shown in table 3.

Finally, the scores of each TS have been used to identify the existence of significant differences between the degrees of perception of TSs with the three study levels measured independently. For that, the Kruskal Wallis non-parametric test was applied, showing evidence only on the internal TS, where significant differences between the study levels (pvalor $=0.04322$ ) are represented. See figure 2.
Table 3. Results of association and correspondence analysis.

\begin{tabular}{|c|c|c|c|}
\hline $\begin{array}{l}\text { Study } \\
\text { level }\end{array}$ & TS & p-value & $\begin{array}{c}\text { Corresponde } \\
\text { nce Results }\end{array}$ \\
\hline \multirow{5}{*}{$\begin{array}{c}\text { INITIAL } \\
(\mathrm{n}=18 \\
\text { students })\end{array}$} & legislative & \multirow{3}{*}{0.009} & Preferred \\
\hline & executive & & preferred \\
\hline & juditial & & not preferred \\
\hline & internal & \multirow{2}{*}{0.011} & preferred \\
\hline & external & & not preferred \\
\hline \multirow{9}{*}{$\begin{array}{c}\text { INTERM } \\
\text { EDIATE } \\
(\mathrm{n}=15 \\
\text { students })\end{array}$} & legislative & \multirow{3}{*}{0.0004} & not preferred \\
\hline & executive & & preferred \\
\hline & juditial & & preferred \\
\hline & Monárchical & \multirow{4}{*}{0.0003} & preferred \\
\hline & Hierarchical & & $\begin{array}{l}\text { Unclear } \\
\text { preference }\end{array}$ \\
\hline & Oligarchical & & Preferred \\
\hline & Anarchical & & Preferred \\
\hline & Internal & \multirow{2}{*}{0.004} & not preferred \\
\hline & External & & preferred \\
\hline \multirow{5}{*}{$\begin{array}{c}\text { FINAL } \\
(\mathrm{n}=5 \\
\text { students })\end{array}$} & legislative & \multirow{3}{*}{0.036} & not preferred \\
\hline & executive & & Preferred \\
\hline & judicial & & preferred \\
\hline & liberal & \multirow{2}{*}{0.048} & preferred \\
\hline & conservative & & not preferred \\
\hline
\end{tabular}

The correspondence have been validated statistically $(\mathrm{p}<0.05)$. Source: self-made.

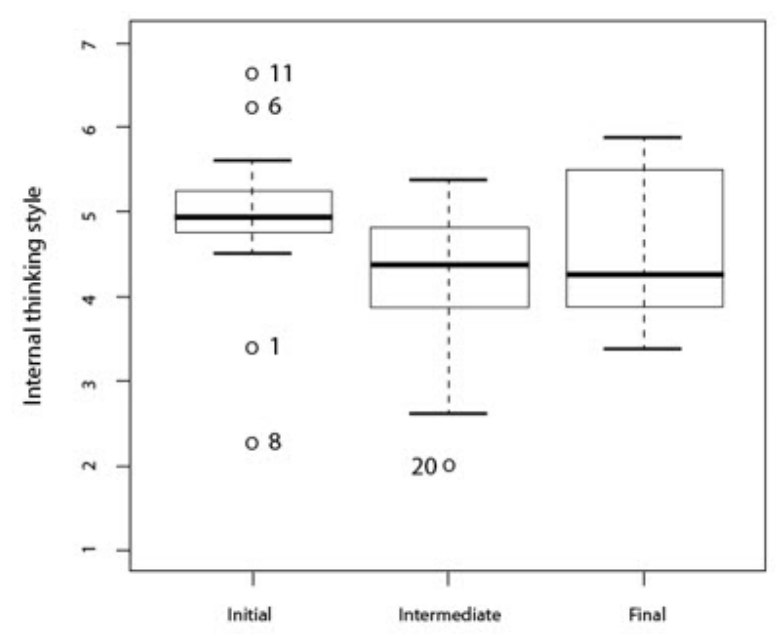

Figure 2. Distribution of internal TS, regarding the three independently studied levels. Source: self-made.

\subsection{Comparisons: RCGP and students}

We consider necessary to emphasize that the sample size of the investigation $(n=38)$ has limited the statistical analysis scope, even considering the fact that the questionnaire was taken by $88 \%$ of the program students. However, statistically valid associations are recognized between the TSs of students for each level in its dimensions, which, by using 
the RCGP, are possible to be compared. In this regard, we refer only to the styles recognized by the RCGP.

In regards to the initial level, a clear association is recognized in the functions of thinking, showing preferences for the legislative and executive styles, which is in accordance with the RCGP. This does not happen in the scopes of thinking, since preferences of the internal style are evident, with the external style being preferred according to the RCGP. This information was implicitly stated in the interview with the director, when characterizing the students just entering into the program. In this sense, the comparison is consistent with the data.

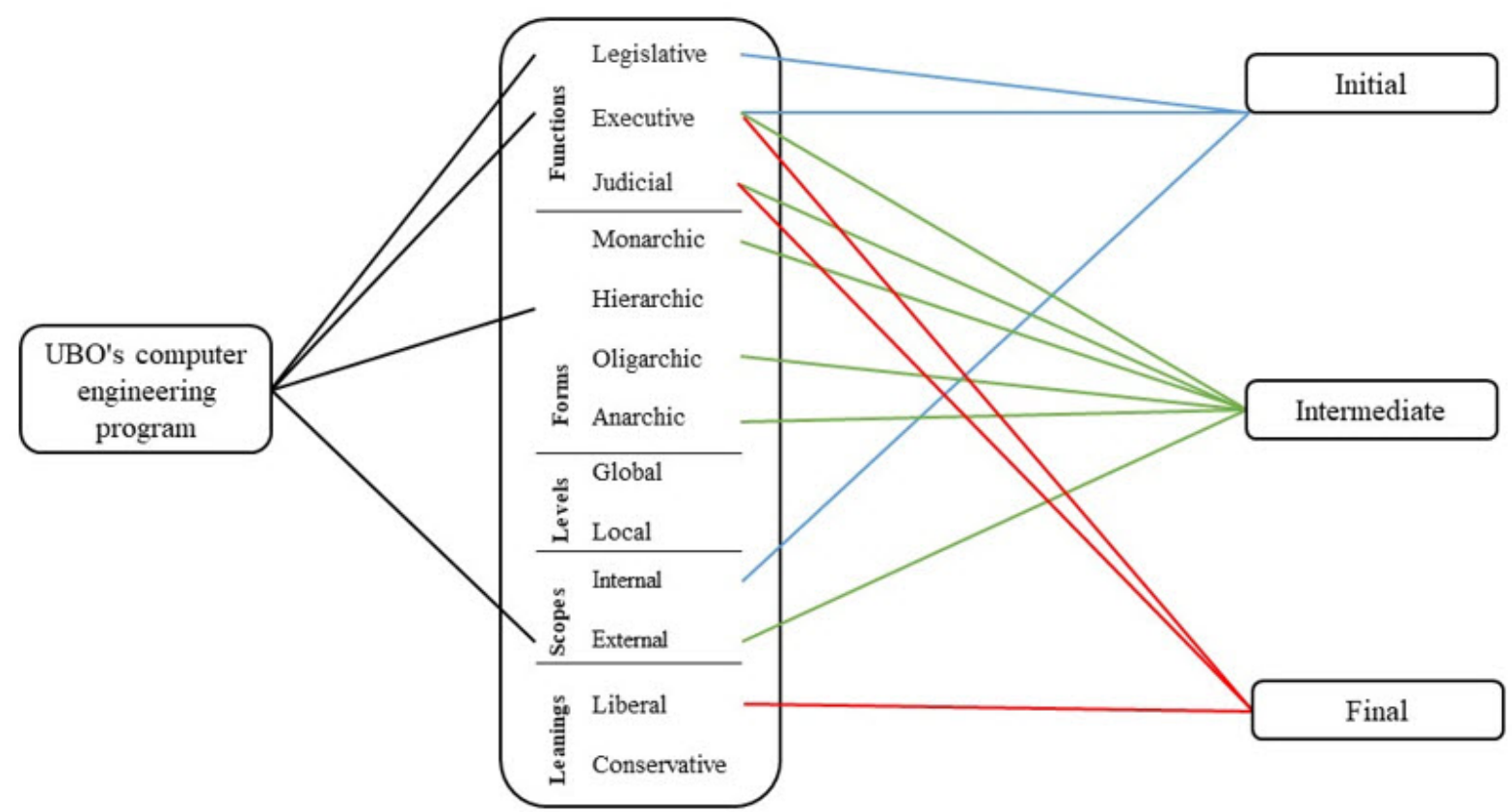

Figure 3. Dynamics of the preferences described by the students, knowing the institutional preferences

From the functions of thinking on the inter-mediate level, a correspondence with the executive style is recognized and the preference towards the legislative style disappears. In regards to the forms of thinking, preferences for each style emerge, except the one preferred by the RCGP (preference is unclear), showing clear differences with respect to what the institution expects from its students. Regarding the scope of thinking, the preferences of the intermediate level tally with the RCGP results (external style).

We can observe that there are coincidences of preferences, both at the final and intermediate level, for the executive and judicial styles. However, in none of these two levels there is a preference for the legislative style (see figure 3).

\section{DISCUSSIONS}

This investigation positions the cognitive dimension as a study source for the professional training processes. In this regard, the RCGP model provides valuable information that can be used to update and keep perfect- ing study programs, teaching practices and applicant/graduation profiles. The RCGP model is highlighted. The considered methodology features make up an instrument that allows to put together the declared expected learning results, coming from multiple sources that affect the formation process. Moreover, the axes in the Figure 1 provided an interpretative structure of the data, enabling us to characterize and suggest a socio-economic underlying situation of the students and, therefore, the results as well.

We consider relevant that the RCGP encompasses the specific activities expected to be done at the end of the professional training process, letting us identify - in an easier manner - the Computer Engineers trained by the UBO through the TSs, without finding a tool of similar range in the literature of specialty. In this sense, the RCGP articulates the social information with the economic data of both the students and the program, being a distinctive element in comparison with other studies, with the purpose of being used to enhance professional formation in general. Its construction and use allowed us to discover 
the preferences for the legislative, executive, hierarchical and external TSs in the Computer Engineering program imparted by the UBO.

Regarding research associated with the education of the engineer, Cropley (2015) high-lights the importance of creativity in the practice of the engineer, which is connected with the legislative and liberal thinking styles (Zhang et al., 1998). In this regard, the data of the present qualitative analysis highlight that creativity should be a focus of interest in training (Cropley, 2015, Ghersi and Miralles, 2014, Lopez et al., 2010), but also, figure 3 indicates that the legislative style is preferred only in the initial state, and the liberal inclination in the final state. This provides, in addition to a concern for engineering training programs, an antecedent for conducting future research.

In addition, it should be noted that no research has been found that characterizes the preferences of the institution's thinking styles. In this regard, the results found are consistent with research associated with engineering education, such as Lee and Sidhu (2015) or Kim (2011), which express preferences towards the pragmatic, the creative and the constant order of tasks that must perform an engineer. These results, together with the executive style, have been granted by the RCGP model.

\section{CONCLUSIONS}

At the Initial level, it is concluded that the students prefer the internal style, differing from the scope of external thinking that the RCGP model demonstrates, suggesting that proposal-making should be directed to external style from the first year. The nature of this proposal may be of a pedagogic origin (e.g., exhibitions, discussion tables) that succeeds in cultivating socialization processes, whether between peers or with people from areas where the multidisciplinary character of the students' future work is laid out. On the other hand, the preferences of functions of thinking are similar with those of the RCGP (legislative and executive).

At the Intermediate level, a similarity of external thinking of the RCGP results is evidenced, which could be the consequence of simply dealing with a different human group, or the actual initial maturation that exists in the students of the program. From the director's perception, the great majority of students from this program are introverted (see section 3.1.2); therefore, the actions declared by the director strengthen on a different degree the academic and labor preferences that one has at this level.

In relation to the functions of thinking, the similarity with the executive style is maintained, but the same does not happen with the legislative style. The executive style is recognized in training, for instance, in mathematical or accounting courses that have a utilitarian purpose of such knowledge for the training, and are located at the beginning of the curriculum structure. As an example, in general, mathematical demonstrations are not required in the computer-engineering mathematics courses, but they understand the use of binary systems and solve mathematical problems in related areas of the career, developing other skills like, a logical-deductive and structural rationale, granted by the use of mathematics.

In the final level, preferences similar to those recognized in the intermediate level were found; there are preferences for the executive style and not for the legislative style. Given the situation, the present study suggests considering milestones in the training that encourage the legislative style. A possibility to recognize these kind of milestones is in the final year projects, although these type of preferences, in a work environment, could be initiated from different moments of the formation process, since other moments could be included for creation, project planning and the solving of problems, related to the discipline with different complexity levels, which will allow for the adjusting and flexibilization of the styles towards what the institution needs.

Although, the data does not possess a longitudinal scope, it is interesting to see the distribution results of the internal TS in the three levels (Figure 3), since one appreciates the analysis of preferences throughout the program for one specific group of students, remaining in the framework of discussion and in the prospectives for the future scientific breakthroughs in the area. In this regard, this study could be a basis for developing longitudinal research, because the methodological framework presented in this study allows, with the help of the RCPG model, to identify institutional preferences, contributing to the training of university students from a cognitive perspective.

Considering all the factors we have discussed, it's clear to conclude that the present study provides information of interest for the Computer Engineering program in the UBO, and for the professional training of Computer Engineering in general, highlighting that exploring, recognizing and/or promoting TSs 
Huincahue, J., Gaete-Peralta, C, Garrido Véliz, V. (2019). Thinking styles and computer engineering training: an empirical study, International Journal of Cognitive Research in Science, Engineering and Education (IJCRSEE), 7(1), 21-33

profiles in the performance of future work tasks, will contribute to building human capital of excellence for specific tasks required in our society.

\section{ACKNOWLEDGEMENTS}

The authors express their gratitude to University of Bernardo O'Higgins for making this project possible.

\section{Conflict of interests}

The authors declare no conflict of interest.

\section{REFERENCES}

Agency of Education Quality [AEQ] (2018a). Resultados prueba SIMCE [Results SIMCE test]. Retrieved from: https://www.agenciaeducacion.cl/ estudios/biblioteca-digital/resultados/

Agency of Education Quality [AEQ] (2018b). Resultados SIMCE revelan pocos avances en la última década y grandes desafios en media [SIMCE results show poor development in the last decade and big challenges in second level of secondary]. Informes Agencia de la Calidad de la Educación. Retrieved from: https://www.agenciaeducacion. $\mathrm{cl} /$ noticias/resultados-simce-revelan-avancesla-ultima-decada-grandes-desafios-media/

Betoret, F. D. (2012). Análisis de los estilos de pensamiento que utilizan los profesores españoles en el aula Examining Spanish Teachers' Classroom Thinking Styles. [Analysis of thinking styles they use spanish teachers in classroom]. Revista de Educación, 358, 497-522. DOI: 104438/1988-592X-RE-2010-358-088

Bishop, C., \& Foster, C. (2011). Thinking styles: Maximizing online supported learning. Journal of Educational Computing Research, 44(2), 121139. https://doi.org/10.2190\%2FEC.44.2.a

Cano-Garcia, F., \& Hughes, E. H. (2000). Learning and thinking styles: An analysis of their interrelationship and influence on academic achievement. Educational Psychology, 20(4), 413-430. https://doi.org/10.1080/713663755

Cisterna Cabrera, F. (2005). Categorización y triangulación como procesos de validación del conocimiento en investigación cualitativa. [Categorization and triangulation as validation process of knowledge in qualitative research]. Theoria, 14(1), 61-71. Retrieved from: https://www.redalyc.org/html/299/29900107/

Cortés, J. Ó. L., Arellano, M. A., \& Vázquez, V. S. (2016). Problemática de la enseñanza y evaluación de las matemáticas en la formación para ingenieros [Problematic in the teaching and evaluation of maths in engineering training]. ANFEI Digital, 2(4), 1-9. Retrieved from: http:// anfei.org.mx/revista/index.php/revista/article/ download $/ 198 / 680$

Cropley, D. H. (2015). Promoting creativity and innovation in engineering education. Psychology of Aesthetics, Creativity, and the Arts, 9(2), 161171. Retrieved from: https://psycnet.apa.org/ doi/10.1037/aca0000008

Denzin, N. (1990). Triangulation. In: Keeves, J. (1990) Educational Research, Methodology, and Measurement. An International Handbook. Oxford: Pergamon Press.

Department of Integral Formation [DFI] (2016). Informe Diagnóstico 2016. Anexo: Escuela de Ingeniería en Informática [2016 Diagnostic inform. Anex: School of computer engineering]. Technical inform unpublished of the Vicerrectoría Académica de la Universidad Bernardo O'Higgins. Chile.

Donolo, D. S. (2009). Triangulación: Procedimiento incorporado a nuevas metodologías de investigación. [Triangulation: procedure incorporated to new research methodologies]. Revista Digital Universitaria, 10(8), 2-10. Retrieved from http:/www.revista.unam.mx/vol.10/num8/ art53/int53.htm

Donoso, S., \& Cancino, V. (2018). Caracterización socioeconómica de los estudiantes de educación superior. [Socio-economic characterization of higher education students]. Calidad en la Educación, (26), 205-244. http://dx.doi. org/10.31619/caledu.n26.240

Donoso, S., Donoso, G., \& Arias, Ó. (2018). Iniciativas de retención de estudiantes de educación superior. [Retention initi-atives for students in higher education]. Calidad en la Educación, (33), 1561. http://dx.doi.org/10.31619/caledu.n33.138

Economía y Negocios. (2016). Creerse el cuento. [To buy the story] Retrieved may 20, 2018, from http://www.economiaynegocios.cl/noticias/noticias.asp? $\mathrm{id}=265706$

Gavira, S. A., \& Osuna, J. B. (2015). La Triangulación de Datos como Estrategia en Investigación Educativa [Triangulation data as strategy in educational research]. Revista de Medios y Educación, 47, 73-88. http://dx.doi.org\&10.12795/ pixelbit.2015.i47.05

Gaete-Peralta, C. (2015). Evaluación en Matemática bajo una perspectiva Socio-epistemológica a través del estudio de los Estilos de Pensamiento en estudiantes de Ingeniería [Evaluation in maths from a socioepistemological perspective through thinking styles in students of engineering]. Thesis un-published for obtain degree of master of Didactic of Mathematics, Pontificia Universidad Católica de Valparaíso, Chile.

Garcia Ahumada, F. S. (2005). Estilos de pensamiento en alumnos de Pre-Grado de Medicina. [Thinking styles in un-dergraduate medicine students]. Revista Médica Herediana, 16(3), 190-198. Retrieved from: http://www.scielo.org. pe/scielo.php? script $=$ sci_arttext\&pid $=\mathrm{S} 1018$ 130X2005000300006

George, D., \& Mallery, P. (2003). SPSS for Windows step by step: A simple guide and reference. 11.0 update. Retrieved from: https://wps.ablongman.com/wps/media/ob-jects/385/394732/ george4answers.pdf

Ghersi, I., Miralles, M. (2014). El desarrollo del pensamiento creativo en estudiantes de ingeniería ¿formados para crear? [The development of creative thinking in engineering students. Trained to create?] Proceedings of Iberoamerican Congress of Science, Technology Innovation and Education. Buenos Aires, Argentina.

González-Pienda, J. A., Núñez Perez, J. C., GonzálezPumariega Solis, S., Álvarez Pérez, L., Roces, 
C., González-Castro, P., Bernardo, A., Valle, A., Cabanach, R., Rodríguez, S., \& Rosário, P. (2004). Estilos de pensamiento: análisis de su validez estructural a través de las res-puestas de adolescentes al Thinking Styles Inventory. [Thinking styles: analysis of structural validity through the answer of teens to Thinking Styles Inventory]. Psicothema, 16(1), 139-148. Retrieved from: http://hdl.handle.net/1822/11870

Grigorenko, E. L., \& Sternberg, R. J. (1997). Styles of thinking, abilities, and academic performance. Exceptional children, 63(3), 295-312. https:// doi.org/10.1177\%2F001440299706300301

Gutiérrez, M., \& Krumm, G. (2012). Adaptación y validación del Inventario de Estilos de Pensamiento de Sternberg (TSI) en la provincia de Entre Ríos-Argentina. [Adaptation and validation of the Sternberg's Thinking Styles Inventory (TSI) in the province of Entre Ríos-Argentina] Interdisciplinaria, 29(1). Retrieved from: https:// www.redalyc.org/html/180/18026124003/

Huincahue, J. (2014). Estilos de Pensamiento para la Enseñanza en la Formación Inicial de Profesores de Matemática [Thinking styles for the teaching in the initial training of math teachers]. Proceedings of VI Iberoamerican Congress of Pedagogy, 258-268. Universidad Católica Silva Henríquez, Santiago.

Jisu, H., Delorme, D. E., \& Reid, L. N. (2006). Perceived Third Person effects and consumer attitudes on prevetting and banning DTC advertising. Journal of Consumer Affairs, 40(1), 90-116. https:// doi.org/10.1111/j.1745-6606.2006.00047.x

Kim, M. (2011). The relationship between thinking style differences and career choices for highachieving students. Roeper review, 33(4), 252262. https://doi.org/10.1080/02783193.2011.60 3113

Lee, C. K., \& Sidhu, M. S. (2015). Engi-neering students learning preferences in UNITEN: Comparative study and patterns of learning styles. Educational Technology \& Society, 18(3), 266282. Retrieved from: https://www.j-ets.net/ETS/ journals/18_3/21.pdf

Lizasoain, L., Joaristi, L., Lukas, J. F., \& Santiago, K. (2007). Efectos contextuales del nivel socioeconómico sobre el rendimiento académico en la educación secundaria obligatoria en la Comunidad Autónoma Vasca (España). Estudio diferencial del nivel socioeco-nómico familiar y el del centro escolar. [Contextual effects of the socioeco-nomic level on academic performance in compulsory secondary education in the basque autonomous community (Spain). Differential study of the socioeconomic family level and the school center]. Education Policy Analysis Archives/Archivos Analiticos de Politicas Educativas, 15, 1-37. Retrieved from: http:// www.redalyc.org/articulo.oa?id $=275020546008$

López Martínez, O., \& Martín Brufau, R. (2010). Creative intelligence and thinking styles. Anales De Psicología / Annals of Psychology, 26(2), 254258. Retrieved from https://revistas.um.es/analesps/article/view/109161

Saxena, M. K., \& Aggarwal, S. (2011). Thinking Styles of Prospective Teachers: An Empirical Study. Brics journal of educational research, 1(2), 94101. Retrieved from: http://bricsjer.com/index. $\mathrm{php} / \mathrm{brics} /$ article/view $/ 5 / 0$

SIMCE (2013). Los aprendizajes en la escuela: ampli- ando la mirada de calidad - Resultados SIMCE 2013 [The learnings in the school: expanding the quality vision]. Inform of Agencia de la Calidad de la Educación. Retrieved from: http://www. educacion2020.cl/sites/default/files/conferencia_nacional_resultados_simce_2013_final. pdf

Spangenberg, E. D. (2012). Thinking styles of Mathematics and Mathematical Literacy learners: Implications for subject choice. Pythagoras, 33(3), 1-12. Retrieved from: https://hdl.handle. net/10520/EJC129246

Sternberg, R. J. (1997). Thinking Styles. New York: Cambridge University Press.

Sternberg, R. J. (1999). Estilos de pensamiento. [Thinking styles]. Paidos Iberica, Ediciones S. A. Retrieved from: http://www.paidosdep.com.ar/ $\mathrm{html} /$ indices/ind59212.pdf

Sternberg, R. J., \& Grigorenko, E. L. (1995). Styles of thinking in the school. European Journal of High Ability, 6(2), 201-219. https://doi. org/10.1080/0937445940060211

Sternberg, R. J., \& Grigorenko, E. L. (2001). A capsule history of theory and research on styles. Perspectives on thinking, learning, and cognitive styles, 1-21. https://doi.org/10.4324/9781410605986

UBO (2018). Dirección de Formación Integral. Descripción y Objetivos [Direction of Integral Formation. Description and objectives]. Retrieved july 19, 2018, from http://www.dfi.ubo.cl/descripcion-objetivos/

Valencia, M. M.A. (2000). La triangulación metodológica: sus principios, alcances y limitaciones. limitaciones [The methodological triangulation: their principles, scope and limitations]. Investigación $y$ educación en enfermería, 18(1), 13-26. Retrieved from: http://www.redalyc.org/articulo. oa? id=105218294001

Vargas, G. M. G. (2007). Factores asociados al rendimiento académico en estudiantes universitarios, una reflexión desde la calidad de la educación superior pública. Revista educación, 31(1), 43-63. https://doi.org/10.15517/revedu. v31i1.1252

Zhang, L. F. (2002). Thinking styles: Their relationships with modes of thinking and academic performance. Educational Psychology, 22(3), 331-348. https://doi.org/10.1080/01443410220138557

Zhang, L. F. (2004). Revisiting the predictive power of thinking styles for academic performance. The Journal of Psychology, 138(4), 351-370. https:// doi.org/10.3200/JRLP.138.4.351-370

Zhang, L. F., \& Sternberg, R. J. (1998). Thinking styles, abilities, and academic achievement among Hong Kong university students. Educational Research Journal. 13, 41-62. Retrieved from: http://hdl.handle.net/10722/72219

Zhang, L. F., \& Sternberg, R. J. (2000). Are learning approaches and thinking styles related? A study in two Chinese populations. The Journal of psychology, 134(5), 469-489. https://doi. org/10.1080/00223980009598230 